\title{
PERTUMBUHAN CACING TANAH Eisenia fetida sp. PADA KOMPOS LIMBAH FLESHING
}

\section{THE GROWTH OF EARTHWORM Eisenia fetida sp. ON THE FLESHING WASTE COMPOST}

\author{
Prayitno \\ Balai Besar Kulit, Karet, dan Plastik, Jl. Sokonandi No. 9 Yogyakarta 55166, Indonesia \\ Telp.: +62 274 512929, 563939; Fax.: +62 274563655 \\ E-mail: prayitno_bbkkp@yahoo.com
}

Diterima: 30 Juli 2015 Direvisi: 6 Oktober 2015 Disetujui: 8 Oktober 2015

\begin{abstract}
The use of earthworm as a source of income and a means for managing organic solid waste such as fleshing waste has been widely applied. The aim of this research was to find the optimum ratio between fleshing waste and cow dung in the growing medium of Eisenia fetida sp. This research was conducted by growing the E. fetida sp. earthworm in the medium containing fleshing waste mixed with cow dung. The ratio of fleshing waste and cow dung was varied at 0:100; 10:90; 20:80; 30:70; 40:60; and 50:50. In addition, 2 parts of chopped stubbles per part of every sample was added as a carbon source. The prepared media were fermented for three weeks with EM4 as a starter, followed by incubation of the earthworm for six weeks. The weight and the number of earthworm were evaluated every two weeks. The optimum growth of earthworm was achieved at the 2nd week of incubation with $185.48 \%$ and $121.10 \%$ increase of weight and number of earthworm, respectively, at 40:60 ratio of fleshing waste and cow dung in the growing medium.
\end{abstract}

Keywords: earthworm, fleshing waste, incubation.

\section{ABSTRAK}

Penggunaan cacing tanah sebagai sumber pendapatan dan juga sarana untuk penanganan limbah padat organik seperti limbah fleshing saat ini telah banyak dilakukan. Penelitian ini bertujuan untuk mengetahui kondisi optimal perbandingan antara limbah fleshing dan kotoran sapi untuk pertumbuhan cacing tanah E. fetida sp. Penelitian dilakukan dengan menumbuhkan cacing tanah E. fetida sp. dalam media campuran limbah fleshing dan kotoran sapi dengan variasi perbandingan berturut-turut $0: 100 ; 10: 90 ; 20: 80 ; 30: 70 ; 40: 60 ;$ dan 50:50 dan sebagai tambahan sumber karbon ditambahkan cacahan jerami sebanyak 2 bagian untuk setiap perlakuan. Semua media perlakuan difermentasikan selama tiga minggu dengan bantuan larutan starter EM4, dilanjutkan dengan inkubasi cacing tanah selama enam minggu. Berat serta jumlah cacing tanah dievaluasi setiap dua minggu. Pertumbuhan optimum cacing tanah dicapai pada minggu ke-2 dengan kenaikan bobot cacing tanah sebesar 185,48\% dan jumlah $121,10 \%$ pada perlakuan perbandingan limbah fleshing dengan kotoran hewan 40:60.

Kata kunci: cacing tanah, inkubasi, limbah fleshing.

\section{PENDAHULUAN}

Pada proses pengolahan kulit mentah menjadi kulit tersamak akan dikeluarkan limbah dalam jumlah yang cukup besar baik dalam bentuk limbah cair maupun limbah padat. Untuk mengolah 1 ton kulit mentah yang diawetkan dengan garam akan dihasilkan limbah cair sebesar 35-40 $\mathrm{m}^{3}$ dan limbah padat dari berbagai jenis mencapai $600 \mathrm{~kg}$ (Ozgunay et al., 2007). Limbah padat terbanyak adalah limbah yang didapat dari buang daging (fleshing), dari 1 ton kulit mentah akan menghasil- kan 70 sampai $230 \mathrm{~kg}$ limbah buang daging (Kanagaraj et al., 2006). Limbah buang daging sangat potensial mencemari lingkungan karena limbah ini mengandung sisa-sisa daging dan lemak yang mudah mengalami pembusukan dan degradasi. Menurut Ozgunay et al. (2007) limbah fleshing mempunyai karakteristik sebagai berikut: kadar air: $61,65 \%$, pH: $12,37 \%$, lemak: 53\%, N: 13,1\%, garam: $1,77 \%, \mathrm{SO}_{2}: 439$ ppm dan nilai kalori: 4852 kkal, tidak mengandung logam berat. Telah banyak upaya-upaya dilakukan untuk menangani 
limbah padat industri penyamakan kulit terutama untuk limbah sisa buang daging, diantaranya adanya kandungan lemak yang tinggi dimanfaatkan untuk pembuatan minyak diesel (Colak et al., 2006; Getahun \& Gabiyye, 2013). Prayitno (2013) menggunakan limbah fleshing untuk membuat pupuk organik (kompos casting) dengan bantuan cacing tanah E. fetida sp. dan kompos yang dihasilkan telah digunakan untuk pemupukan tanaman cabai merah (Capsicum annuum L) (Prayitno, 2015). Beberapa tahun terakhir banyak orang telah membudidayakan cacing tanah untuk sumber penghasilan maupun untuk menangani limbah padat organik.

Di dunia terdapat kira-kira 1800 spesies cacing tanah (Brata, 2006), dari jumlah tersebut yang telah dibudidayakan diantaranya cacing tanah dari spesies Megascolex mauritii, Eisenia fetida, Eudrilus eugineae, Perionnyx excavantus, Lampito mauriiti, Eisenia andrei, Lampito rubellus, dan Drawida willis (Manyuchi \& Whingiri, 2014). Cacing tanah merupakan hewan invertebrata yang biasa tinggal di dalam tanah. Roslim et al. (2013) menyatakan bahwa cacing tanah sangat menyukai kotoran hewan yang banyak mengandung unsur $\mathrm{N}$ seperti kotoran sapi. Adanya unsur $\mathrm{N}$ yang tinggi pada limbah fleshing sangat baik untuk pertumbuhan cacing tanah. Untuk media pertumbuhan cacing tanah, limbah fleshing perlu dicampur dengan limbah lain sebagai tambahan baik tambahan sumber karbon maupun mineralmineral yang diperlukan. Sebagai tambahan dapat digunakan bahan-bahan limbah padat organik antara lain dari limbah pasar atau industri makanan (Gurav \& Pathade, 2011; Majlessi et al., 2012), peternakan (Ngo, et al., 2011; Gómez-Brandón et al., 2013), obat herbal (Singh \& Suthar, 2012), dan minyak aromatik (Deka et al., 2011), limbah industri citonelle (Deka et al., 2011), limbah kotoran sapi dan potongan jerami (Prayitno, 2013). Beberapa spesies cacing tanah yang telah dikembangkan antara lain Eisenia fetida (Garg \& Gupta, 2011; Molina et al., 2013), Perionyx ceylanensis (Prakash \& Karmegam, 2010; Paul et al., 2011), Perionyx excavatus (Deka et al., 2011; Pattnaik \& Reddy, 2012), dan Eudrilus eugeniae (Pramanik et al., 2011; Raphael \& Velmourougane, 2011). Salah satu spesies cacing tanah, E. fetida sp. yang masuk dalam famili lumbericidae dan genus Eisenia merupakan spesies cacing tanah yang banyak diusahakan secara komersial, karena hasil budidayanya banyak berhubungan dengan bidang peternakan, pertanian, kesehatan, dan industri. Di bidang pertanian cacing tanah dapat dijadikan sebagai sumber protein hewani bahan pakan ternak dan ikan, karena kandungan proteinnya yang cukup tinggi $74-72 \%$ (Hayati et al., 2011), sedangkan menurut Indriati et al. (2012) dan Mashur et al. (2001) cacing tanah mengandung protein 64$76 \%$ dari berat kering dan 20 jenis asam amino, sumber energi antara 900-1.400 kal. Dalam bidang kesehatan cacing tanah dapat dijadikan sebagai bahan baku industri farmasi dan kosmetika, juga di bidang lingkungan cacing jenis E. fetida sp. dapat merombak bahan-bahan organik sebagai makanannya. Aladesida et al. (2014) menyebutkan bahwa cacing tanah E. fetida sp. mempunyai toleransi temperatur yang cukup lebar dan potensi perkembangannya sangat tinggi dan tidak sangat sensitif dalam pembiakannya. Untuk melihat kemampuan cacing E. fetida sp. dalam merombak bahan organik dari limbah fleshing pada pengolahan kulit, maka perlu dilakukan penelitian sejauh mana perkembangan pertumbuhan cacing tanah $E$. fetida sp. dalam media yang mengandung limbah fleshing. Diharapkan dengan penelitian ini akan meningkatkan hasil budidaya cacing tanah dan dapat mengatasi pencemaran industri penyamakan kulit disebabkan limbah flesing yang dihasilkan.

\section{BAHAN DAN METODE \\ Bahan Penelitian}

Bahan yang digunakan dalam penelitian terdiri atas: cacing tanah Eisenia fetida sp. diperoleh dari hasil pemeliharaan petani peternak cacing di daerah Kasongan, Bantul. Kotoran sapi dari kandang sapi milik penduduk di daerah Sitimulyo, Kabupaten Bantul, D.I.Yogyakarta, Limbah fleshing diperoleh dari laboratorium proses kulit Balai Besar Kulit, Karet dan Plastik di Sitimulyo, Bantul, potongan jerami, starter EM4, gula pasir, dan kapur.

\section{Peralatan Penelitian}

Timbangan kapasitas $5 \mathrm{~kg}$ dan timbangan elektrik, termometer, alat-alat gelas, penyemprot air, ember plastik diameter $50 \mathrm{~cm}$, dan ruangan untuk inkubasi.

\section{Metode Penelitian \\ Penyediaan media}

Kotoran sapi diambil setelah tujuh hari untuk mengurangi kadar air dan amoniak. Limbah fleshing dicuci kemudian dijemur pada sinar matahari 
untuk mengurangi kadar air dan mencegah timbulnya belatung. Limbah fleshing dicampur dengan kotoran sapi dengan perbandingan 0:10 (A); 10:90 (B); 20:80 (C); 30:70 (D); 40:60 (E); dan 50:50 (F) dan semua perlakuan ditambahkan potongan jerami $2 \%$ (sebagai tambahan sumber karbon dan menurunkan nilai keambanan media sehingga cacing dapat mudah mendapatkan oksigen (Prayitno, 2013).

\section{Cara kerja penelitian}

Kotoran sapi dicampur dengan jerami dan limbah fleshing sampai merata, larutan starter dibuat dengan cara mencampurkan $1 \mathrm{~g}$ larutan starter ditambah $1 \mathrm{~g}$ gula pasir dan dilarutkan dalam $100 \mathrm{ml}$ air sumur, diaduk merata dan didiamkan semalam (6-10 jam). Larutan starter dicampurkan dengan media kompos setiap perlakuan sebesar $1000 \mathrm{~g}$ dalam ember plastik dan ditutup dengan karung goni, dibiarkan terjadi fermentasi, suhu diamati dan dijaga antara $40-50^{\circ} \mathrm{C}$, bila suhu lebih $50^{\circ} \mathrm{C}$ dilakukan pengadukan, apabila suhu media sudah konstan pada suhu kamar baru dilakukan penanaman cacing. Untuk setiap media perlakuan ditanam cacing sejumlah 30 ekor dengan berat antara $8-12 \mathrm{~g}$.

\section{Pengamatan}

Penimbangan dilakukan berat awal cacing tanah, dilanjutkan dengan penimbangan saat pengamatan setiap 2 minggu hingga minggu ke-6 (42 hari) (Manyuchi \& Whingiri, 2014). Data yang didapat dianalisis terhadap kenaikan dan penurunan berat serta jumlah cacing tanah yang dinyatakan dalam tingkat pertumbuhan relatif (Relative Growth Rate) (Monebi \& Ugwumba, 2013) sesuai dengan persamaan (1) berikut:

Relative growth rate $(\%)=\frac{W_{t}-W_{i}}{w_{i}} \times 100 \%$

$\mathrm{W}_{\mathrm{t}}$ adalah bobot rata-rata akhir percobaan (g) dan $\mathrm{W}_{\mathrm{i}}$ adalah bobot rata-rata awal (g).

\section{Rancangan percobaan}

Rancangan percobaan yang digunakan adalah Rancangan Acak Lengkap (RAL) pola searah, terdiri dari enam taraf perlakuan campuran kotoran sapi dengan limbah fleshing. Tiap taraf perlakuan mendapatkan tiga kali ulangan sehingga terdapat 18 unit percobaan dan tiap satuan pengamatan media terdiri atas 30 ekor cacing tanah, dan pengamatan dilakukan dalam setiap 2 minggu selama tiga kali pengamatan, dan satu kali saat penanaman.

\section{Analisis data}

Data yang diperoleh dianalisis dengan sidik ragam atau analysis of variance (ANOVA) pada taraf kepercayaan $95 \%$. Perlakuan yang berpengaruh nyata terhadap peubah yang diamati diuji lanjut dengan uji Duncan Multiple Test untuk mengetahui perbedaan di antara perlakuan.

\section{HASIL DAN PEMBAHASAN}

\section{Pertambahan bobot cacing tanah.}

Pertambahan bobot badan cacing merupakan indikasi dari pertumbuhan cacing karena mendapatkan nutrisi yang cukup dari media serta kondisi lingkungan yang sesuai dengan pertumbuhan cacing sebaliknya pertumbuhan yang menurun bobot cacing menandakan kurangnya nutrisi untuk pertumbuhan cacing dan kondisi yang tidak sesuai (Garg et al., 2011; Roslim et al., 2013; dan Siddique et al., 2005). Hasil pengamatan terhadap pertumbuhan cacing tanah E. fetida sp. dalam media dari berbagai perbandingan antara limbah fleshing dengan kotoran sapi disajikan pada Gambar 1. Dari grafik terlihat bahwa untuk setiap perlakuan, berat cacing tanah yang digunakan berkisar antara 8,5-12 g dengan jumlah 30 ekor. Rata-rata pertumbuhan cacing tanah pada media dengan perbandingan antara limbah fleshing dan kotoran sapi 0:100 menunjukkan adanya penurunan berat pada pengamatan minggu ke- 2 , ke- 4 , dan ke- 6 berturutturut dari berat awal 8,93 g menjadi 2,54; 1,30; dan $0,98 \mathrm{~g}$ atau mengalami kecepatan pertumbuhan relatif $-89 \%$, demikian juga pada media dengan

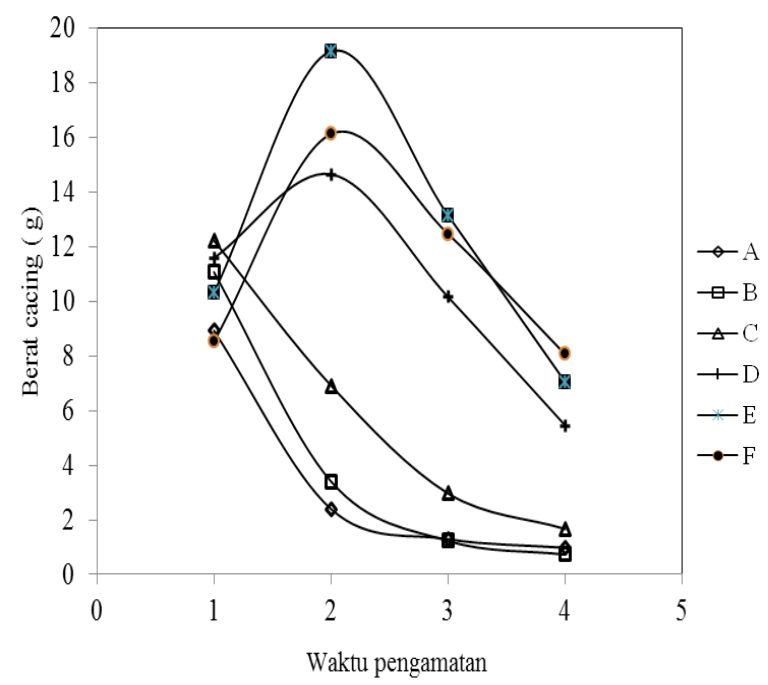

Gambar 1. Grafik berat cacing pada awal dan setiap 2 minggu pengamatan. Perbandingan limbah fleshing : kotoran sapi (A) 0:100, (B) 10:90, (C) 20:80, (D) 30:70, (E) 40:60, dan (F) 50:50. 1, 2, 3, 4: pengamatan minggu ke- $0,2,4,6$. 
perlakuan perbandingan antara limbah fleshing dengan kotoran sapi sebesar 10:90 dan 20:80 terjadi penurunan bobot cacing tanah berturut-turut dari $11,07 \mathrm{~g}$ menjadi 3,$41 ; 1,23$; dan $1,67 \mathrm{~g}$ dan dari $12,23 \mathrm{~g}$ menjadi 6,$92 ; 2,97$; dan $1,67 \mathrm{~g}$ atau mengalami kecepatan pertumbuhan relatif berturut-turut $-85 \%$ dan $-86 \%$. Penurunan bobot cacing ini kemungkinan disebabkan karena ketidakcukupan kandungan protein dari media pertumbuhan yang digunakan. Monebi \& Ugwumba (2013) dalam penelitian pertumbuhaan cacing tanah Eudrilus eugeniae sp. menggunakan beberapa media, menyatakan bahwa dengan media selulosa substrat yang dicampur tanah dengan perbandingan 1:1 menghasilkan berat cacing tertinggi dibanding dengan media tanah tanpa selulosa, hal ini menandakan bahwa unsur-unsur organik yang berupa protein dan sumber karbon sangat diperlukan pada pertumbuhan cacing tanah. Penurunan berat cacing tanah yang terjadi pada penelitian ini kemungkinan disebabkan dengan 100, 90, dan 80 bagian kotoran hewan ditambah 2 bagian cacahan jerami belum mencukupi untuk nutrisi pertumbuhan cacing tanah dan kemungkinan cacahan jerami yang ditambahkan kurang terdegradasi sempurna karena mengandung lignin sehingga tidak dapat dicerna oleh cacing. Untuk media pertumbuhan dengan perlakuan perbandingan antara limbah fleshing dan kotoran sapi berturut-turut 30:70; 40:60; dan 50:50 pada pengamatan minggu ke-2, ketiga perlakuan menunjukkan adanya kenaikan bobot cacing tanah namun pada pengamatan minggu ke-4 dan ke-6 kembali terjadi penurunan. Berturut-turut dari $11,59 \mathrm{~g}$ menjadi 14,$66 ; 10,16$; $5,46 \mathrm{~g}$ dan dari $10,33 \mathrm{~g}$ menjadi 19,$16 ; 13,15$; dan 7,05 g serta dari 8,54 g menjadi 16,$13 ; 12,47$; dan 8,06 g. Dari data diketahui bahwa kecepatan tumbuh cacing sampai dengan minggu ke-2 dengan perlakuan perbandingan limbah fleshing dan kotoran hewan $30: 70 ; 40: 80$; dan 50:50 berturutturut sebesar 26,49; 85,48; dan 88,88\%. Dari data tersebut kenaikan bobot cacing pada 2 minggu pertama diduga oleh karena adanya degradasi dari limbah sisa buang daging yang pada dasarnya lebih mudah diurai dari pada potongan jerami yang mengandung selulosa dan lignin sehingga hasil degradasi limbah sisa buang daging dapat digunakan sebagai sumber makanan cacing. Sedangkan pada minggu ke-4 dan 6 terjadi penurunan dari berat dengan kecepatan tumbuh cacing berturut-turut $-52,89$; $-33,79$; dan $-5,62 \%$, keadaan ini mengindikasikan bahwa sisa media tersebut dimungkin- kan tidak cukup nutrisi untuk pertumbuhan cacing. Zat yang mempunyai peranan penting pada pertumbuhan cacing adalah protein. Mashur et al. (2001) menyatakan kadar protein paling optimal untuk pertumbuhan cacing adalah $9-15 \%$, menurut Ogunay et al. (2007) limbah fleshing mempunyai kadar air: $61,65 \%$; pH: 12,37 ; lemak: $53 \%$; $\mathrm{N}: 13,1 \%$; garam: $1,77 \%$; $\mathrm{SO}_{2}: 439 \mathrm{ppm}$ dan nilai kalori $4852 \mathrm{kkal} / \mathrm{kg}$, dengan kadar $\mathrm{N}=1,77 \%$ berarti setara dengan $38,32 \%$ protein sehingga pada setiap media akan mengandung protein dari limbah fleshing berturut-turut sebesar 0; 3,83; 7,66; 11,49; 15,32; dan 19,15\%. Achmad et al. (2010) menyatakan bahwa kotoran sapi mengandung unsur $\mathrm{N}$ sebesar $0,65 \%$ atau setara dengan $14,07 \%$ protein sehingga untuk media dengan perlakuan perbandingan limbah fleshing dengan kotoran sapi $0: 100 ; 10: 90 ; 20: 80 ; 30: 70 ; 40: 60$; dan 50:50 dari hasil perhitungan mangandung total protein berturut-turut sebesar 14,$07 ; 16,50 ; 18,93 ; 21,34 ; 23,76$ dan $26,19 \%$ protein. Dari hasil penelitian terlihat bahwa kenaikan jumlah limbah fleshing yang ditambahkan akan meningkatkan pertumbuhan berat cacing. Untuk pertumbuhan cacing tanah seperti pada organisme lain dituntut adanya kesetimbangan antara unsur $\mathrm{C}$ dan N. Kadar unsur C pada kotoran sapi 9.7\% (Achmad et al., 2010) sehingga untuk pertumbuhan cacing tanah media perlu ditambah sumber karbon dari limbah fleshing dan juga dari cacahan jerami. Dimungkinkan sampai dengan minggu ke-4, protein dan karbon sudah berkurang digunakan oleh cacing tanah yang menyebabkan terjadinya penurunan berat cacing dan kemungkinan juga cacing jenis $E$. feti$d a$ sp. tidak menyukai media dari potongan jerami yang ditambahkan.

Dari analisis ragam (Tabel 1) menunjukkan bahwa faktor media berpengaruh nyata pada pertumbuhan cacing $\left(\mathrm{F}_{\mathrm{ht}=51,91}<\mathrm{F}_{\mathrm{tb}=2,42}\right)$, kemudian dilanjutkan dengan analisa Duncan dengan LSD 5\% (Tabel 2 dan Tabel 3).

\section{Faktor media}

Pengaruh perlakuan media terhadap pertumbuhan cacing tanah adalah seperti disajikan pada Tabel 2. Dari Tabel 2. terlihat bahwa pertumbuhan cacing tanah E. fetida sp., akan meningkat seiring dengan meningkatnya jumlah limbah fleshing yang ditambahkan. Hal tersebut dimungkinkan karena adanya degradasi protein dari limbah fleshing yang akan menghasilkan unsur $\mathrm{N}$ yang dapat diserap untuk pertumbuhan cacing. Prayitno (2015) 
Tabel 1. Analisis ragam

\begin{tabular}{lrrrrl}
\hline \multicolumn{1}{c}{$\begin{array}{c}\text { Sumber } \\
\text { Keragaman }\end{array}$} & \multicolumn{1}{c}{ d.b } & \multicolumn{1}{c}{ SS } & \multicolumn{1}{c}{ MS } & Fht & Ftb 5\% \\
\hline Ulangan & 2 & 14,88 & 7,44 & & \\
Treat & 23 & $1.951,99$ & 84,87 & & \\
Media & 5 & 920,32 & 184,06 & 51,91 & 2,42 \\
Waktu Inkubasi & 3 & 739,59 & 246,53 & 69,52 & 2,81 \\
Interaksi & 3 & $8.265,02$ & $2.755,01$ & 776,91 & 2,81 \\
Eror & 48 & 170,21 & 3,55 & & \\
\hline
\end{tabular}

menyatakan bahwa kandungan unsur $\mathrm{N}$ meningkat dari $1,53 \%$ pada pengukuran saat pencampuran, naik menjadi $2,60 \%$ pada inkubasi minggu ke-6 dengan menggunakan campuran limbah fleshing dengan limbah kotoran sapi 50:50 bagian. Media dengan perlakuan $\mathrm{A}$ dan $\mathrm{B}$ tidak menunjukkan perbedaan nyata untuk pertumbuhan cacing tanah, ini berarti bahwa penambahan limbah fleshing pada media belum mempengaruhi pertumbuhan. Dengan penambahan limbah fleshing sehingga perbandingan antara kotoran sapi dengan limbah fleshing menjadi 80:20 telah mempengaruhi pertumbuhan cacing tanah. Dan peningkatan lebih lanjut limbah fleshing secara nyata akan meningkatkan pertumbuhan cacing tanah. Hal tersebut sesuai dengan Mashur et al. (2001), bahwa kebutuhan optimal untuk pertumbuhan cacing adalah 9-15\%, untuk media perlakuan $\mathrm{C}$ menunjukkan beda nyata baik untuk media dengan perlakuan A, $\mathrm{B}$ maupun $\mathrm{E}$ dan $\mathrm{F}$ sedangkan media dengan perlakuan $\mathrm{D}$ dan $\mathrm{F}$ tidak menunjukkan adanya beda nyata untuk pertumbuhan berat cacing. Optimum pertumbuhan cacing E. fetida sp. terjadi pada media dengan perlakuan $\mathrm{E}$ atau kompos dengan perbandingan limbah fleshing dan kotoran sapi 40:60

Tabel 2. Analisa LSD media

\begin{tabular}{cccc}
\hline $\begin{array}{c}\text { Media } \\
\text { Fleshing: } \\
\text { Kotoran sapi }\end{array}$ & Total & Rerata & $\begin{array}{c}\text { Notasi } \\
\text { LSD } 5 \%\end{array}$ \\
\hline $0: 100$ & 41,25 & 3,44 & $\mathrm{a}$ \\
$10: 90$ & 49,33 & 4,11 & $\mathrm{a} \mathrm{b}$ \\
$20: 80$ & 71,33 & 5,94 & $\mathrm{c}$ \\
$30: 70$ & 125,58 & 10,47 & $\mathrm{~d} \mathrm{e}$ \\
$40: 60$ & 135,61 & 11,30 & e f \\
$50: 50$ & 149,09 & 12,42 & $\mathrm{f}$ \\
\hline
\end{tabular}

Keterangan: Huruf yang sama pada kolom notasi menunjukkan tidak ada beda nyata. $\mathrm{F}_{\text {Hitung }}>\mathrm{F}_{\text {tabel }}$ Notasi LSD 5\% $=1,61$. tidak menunjukkan adanya beda nyata dengan perlakuan perbandingan limbah fleshing dan kotoran sapi 50:50.

\section{Faktor inkubasi}

Waktu inkubasi akan sangat menentukan dari pertumbuhan cacing tanah. Dengan kecukupan nutrisi untuk pertumbuhan dan kesesuaian lingkungan untuk tumbuh seperti suhu, kelembaban akan meningkatkan pertumbuhan cacing tanah seiring dengan meningkatnya waktu. Bhattacharjee et al. (2014) menyatakan berat cacing akan meningkat tajam pada hari ke-15, dan tetap naik sampai hari ke-30 setelah itu menurun, waktu optimum pertumbuhan cacing tanah jenis Pontoscolex corethrurus sp. dicapai pada hari ke-30 dengan media dari tanah untuk pertumbuhan tanaman karet. Pada penelitian ini waktu inkubasi 2 minggu tidak menunjukkan beda nyata untuk pertumbuhan cacing tanah dengan waktu inkubasi awal seperti disajikan pada Tabel 3, namun ada beda nyata dengan waktu inkubasi 4 dan 6 minggu, sedangkan untuk waktu inkubasi 4 minggu menunjukkan adanya beda nyata pada berat cacing dengan waktu inkubasi 6 minggu. Waktu inkubasi optimum adalah 2 minggu. Keadaan ini mengindikasikan bahwa untuk pertumbuhan ca-

Tabel 3. Analisa LSD waktu inkubasi

\begin{tabular}{cccc}
\hline $\begin{array}{c}\text { Treatment } \\
\text { inkubasi }\end{array}$ & Total & Rerata & $\begin{array}{c}\text { Notasi } \\
\text { LSD 5\% }\end{array}$ \\
\hline 2 & 188,4816 & 31,4136 & $\mathrm{a}$ \\
0 & 188,0656 & 31,3443 & $\mathrm{a} \mathrm{b}$ \\
4 & 123,8178 & 20,6363 & $\mathrm{c}$ \\
6 & 71,8253 & 11,9709 & $\mathrm{~d}$ \\
\hline
\end{tabular}

Keterangan: Huruf yang sama pada kolom notasi menunjukkan tidak ada beda nyata. $\mathrm{F}_{\text {tabel }}>\mathrm{F}_{\text {hitung }}$ Notasi LSD 5\% $=1,8827$. 


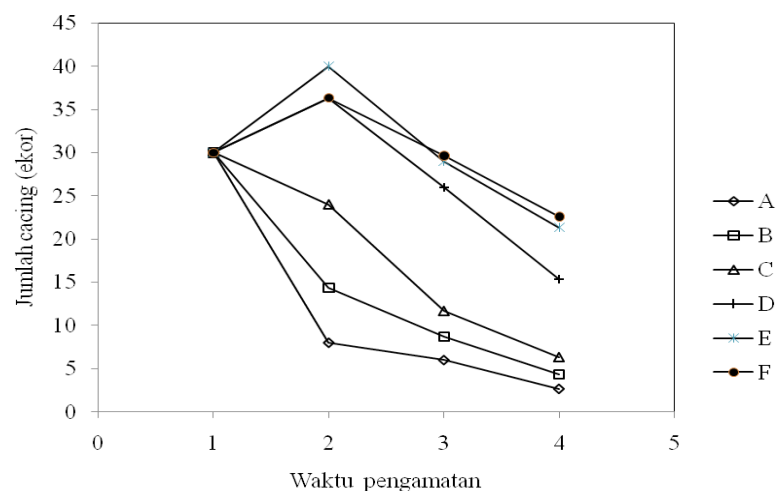

Gambar 2. Grafik jumlah cacing pada awal dan setiap 2 minggu pengamatan. Perbandingan limbah fleshing : kotoran sapi (A) 0:100, (B) 10:90, (C) 20:80, (D) 30:70, (E) 40:60, dan (F) 50:50. 1, 2, 3, 4: pengamatan minggu ke- $0,2,4,6$.

cing dengan inkubasi yang lama juga diperlukan kecukupan nutrisi terutama protein. Pada kondisi percobaan protein telah mulai berkurang untuk masa inkubasi 4 dan 6 minggu.

\section{Pertambahan jumlah cacing}

Pertambahan jumlah cacing dimungkinkan karena adanya pembiakan dari cacing yang akan menghasilkan kokon (telur cacing) dan terbentuknya anakan cacing. Pembiakan cacing memerlukan kondisi yang memadai untuk pertumbuhan cacing khususnya kecukupan akan nutrisi. (Brintha, 2015). Hasil penelitian perkembangan jumlah cacing tanah $E$. fetida sp. seperti disajikan pada Gambar 2. Dari grafik pada Gambar 2 terlihat bahwa mortalitas terjadi pada media dengan perlakuan $\mathrm{A}, \mathrm{B}$, dan $\mathrm{C}$ dari jumlah awal masingmasing rata-rata 30 ekor cacing berturut-turut berkurang menjadi rata-rata $8 ; 14,33$; dan 24 untuk inkubasi selama 2 minggu dan berturut-turut menjadi rata-rata $6 ; 8,67$ dan 11,67 pada inkubasi 4 minggu dan menjadi rata-rata 2,$67 ; 4,33$; dan 6,33 pada inkubasi 6 minggu.

Terjadinya mortilitas tersebut kemungkinan disebabkan kebutuhan nutrisi yang belum sesuai terutama untuk sumber protein. Pada perlakuan ini jumlah limbah sisa daging yang ditambahkan masih sedikit sehingga kandungan protein yang ada tidak mencukupi untuk konsumsi 30 ekor cacing dan kemungkinan juga disebabkan serasah yang berupa potongan jerami belum terhancurkan dengan sempurna sehingga kandungan lignin yang keras tidak dapat diserap oleh cacing. Sedangkan pada Media D, E, dan F terjadi penambahan jumlah cacing dari rata-rata 30 ekor menjadi ber- turut-turut rerata 36,$33 ; 40$; dan 36,33 ekor pada 2 minggu inkubasi kemudian terjadi penurunan kembali pada waktu inkubasi 4 dan 6 minggu menjadi berturut-turut 26; 29; dan 29,67 ekor untuk masa inkubasi 4 minggu dan 15,33; 21,33; dan 22,6 ekor untuk masa inkubasi 6 hari. Kenaikan jumlah cacing pada minggu ke-2 kemungkinan disebabkan adanya kecukupan nutrisi dan kondisi lingkungan yang memadai. Jumlah limbah fleshing yang cukup dan sudah mengalami degradasi akan dapat diserap oleh cacing. Fadaee (2012) menyatakan bahwa $E$. fetida sp. dewasa akan mengeluarkan kokon untuk setiap 3 hari. Roslim (2013) menyatakan untuk cacing merah 1 kokon akan menghasilakan 4-7 ekor cacing sehingga kemungkinan untuk penambahan cacing pada minggu ke-2 hanya ada satu kokon. Mortilitas terjadi setelah nutrisi dan makanan tidak lagi mencukupi. Menurut Manshur et al. (2001) dan Monroy et al. (2006) pertumbuhan dan reproduksi cacing tanah sangat dipengaruhi oleh kecukupan nutrisi dari media dan juga kondisi lingkungan. Kondisi optimum untuk cacing tanah dapat menghasilkan kokon adalah temperatur rata-rata $27,64 \%$, kelembaban $61,23 \%$. Pada penelitian ini dimungkinkan nutrisi sudah berkurang untuk pertumbuhan cacing tanah selama 2 minggu. Sehingga pada minggu ke-4 dan berlanjut pada minggu ke-6. Nutrisi sudah tidak mencukupi untuk pertumbuhan cacing tanah. Menurut Dynes (2003), cacing E. fetida sp. mulai dewasa untuk bertelur setelah berumur 8,4 minggu dari saat menetas jadi dengan waktu 6 minggu dimungkinkan cacing belum cukup dewasa untuk menghasilkan kokon.

\section{KESIMPULAN}

Limbah sisa buang daging hasil samping dari proses penyamakan kulit dapat digunakan untuk campuran media pertumbuhan cacing tanah Eisenia fetida sp. Perbandingan terbaik dicapai pada media dengan campuran antara kotoran hewan dan limbah fleshing dan potongan jerami pada perbandingan 60:40. Waktu inkubasi optimum dengan bobot media $1.000 \mathrm{~g}$ untuk starter cacing Eisenia fetida $\mathrm{sp}$. 10,33 g dicapai pada minggu ke-2 dengan kenaikan berat cacing mencapai 19,16 $\mathrm{g}$ atau kecepatan tumbuh relatif $85,48 \%$ dengan pertambahan jumlah cacing sebesar 33,33\%.

\section{UCAPAN TERIMA KASIH}

Ucapan terima kasih kami tujukan kepada Kepala Balai Besar dan Kepala Bidang SARS Ba- 
lai Besar Kulit, Karet dan Plastik Yogyakarta atas pengarahan serta fasilitas yang diberikan sehingga penelitian ini dapat terlaksana.

\section{DAFTAR PUSTAKA}

Achmad, K. T. B., Hidayati, Y. A., Abdullah, N., \& Sutendy, A. (2010). The effect of Lumbricus rubellus seedling density on earthworm biomass and quantity as well as quality of kascing in vermicomposting of cattle feces and bagasse mix. Lucrari Stiintifice Journal, 54(15), 54-59.

Aladesida, A. A., Owa, S. O., Dedeke, G. A., \& Adewoyin, O. A. (2014). Prospects and challenges of vermiculture practices in southwest Nigeria. African Journal of Environmental Science and Technology, 8(3), 185-189.

Bhattacharjee, S., Dey, A., \& Chaudhuri, P. (2014). Growth and reproduction of Pontoscolex corethrurus in the mineral soils of different age groups of rubber (Hevea brasiliensis) plantations under laboratory conditions. Annals of Biological Research, 5(7), 1-9.

Brata, B. (2006). Pertumbuhan tiga spesies cacing tanah akibat penyiraman air dan pengapuran yang berbeda. Jurnal Ilmu-Ilmu Pertanian Indonesia, 8(1), 69-75.

Brintha, N., Srijayam, M., Elampharithi, V., \& Manimegala, G. (2015). Utilization of municipal solid waste mixed with horse dung by using earthworm Perionyx excavates. International Journal of Advanced Research in Biological Sciences, 2(3), 295-300.

Colak, S., Zengin, G., Özgűnay, H., Sari, Ö., \& Yuceer, H. S. L. (2006). A New and environmental friendly method for utilization of leather industry fleshings: Biodiesel. In IULTCS Euro-congress, Istanbul, Turkey.

Deka, H., Deka, S., Baruah, C. K., Das, J., Hoque, S., Sarma, H., \& Sarma, N. S. (2011). Vermicomposting potentiality of Perionyx excavatu for recycling of waste biomass of Java citronella - An aromatic oil yielding plant. Bioresource Technology, 102(24), 11212-11217.

Dynes, R. (2003). Earthworms: Technology information to enable the development of earthworm production (03/085 pp. 1-5). Canberra, Australia: Rural Industries Research and Development Corporation.

Fadaee. R. (2012). A review on earthworm Eisenia fetida and its applications. Annals of Biological Research, 3(5), 2500-2506.

Garg, V. K., \& Gupta, R. (2011). Optimization of cow dung spiked pre-consumer processing vegetable waste for vermicomposting using Eisenia fetida. Ecotoxicology and Environmental Safety, 74(1), 19-24.

Getahun, E., \& Gabiyye, N. (2013). Experimental investigation and characterization of biodiesel production from leather industry fleshing wastes. International Journal of Renewable and Sustainable Energy, 2(3), 120-129.

Gómez-Brandón, M., Lores, M., \& Domínguez, J. (2013). Changes in chemical and microbiological properties of rabbit manure in a continuousfeeding vermicomposting system. Bioresource Technology, 128, 310-316.

Gurav M.V., \& Pathade G. R. (2011). Production of vermicompost from temple waste (Nirmalya): A Case Study. Universal Journal of Environmental Research and Technology, 1(2), 182-192.

Hayati, S. N., Herdian, H., Damayanti, E., Istiqomah, L., \& Julendra, H. (2011). Profil asam amino ekstrak cacing tanah (Lumbricus rubbellus) terencapsulasi dengan metoda spray drying. Jurnal Teknologi Indonesia, 34(Khusus), 1-7.

Indriati, G., Sumitri, M., \& Widiana, R. (2012). Pengaruh air rebusan cacing tanah (Lumbricus rubellus) terhadap pertumbuhan bakteri Escherichia coli. Dalam Seminar BKS PTN-B MIPA Biologi. Medan, Indonesia: Universitan Negeri Medan.

Kanagaraj, J., Vellapan, K. C., Chandra Babu, N. K., \& Sadulla, S. (2006). Solid wastes generation in the leather industry and its utilization for cleaner environment-A review. Journal of Scientific and Industrial Research, 65(7), 541-548.

Majlessi, M., Eslami, A., Saleh, H. N., Mirshafieean, S., \& Babaii, S. (2012). Vermicomposting of food waste: assessing the stability and maturity. Iranian Journal of Environmental Health Science \& Engineering, 9(13), 25-30.

Manyuchi, M. M., \& Whingiri, E. (2014). Effect of vermicomposting period, substrate quantity, cow dung composition and their interactions on Eisenia fetida during vermicomposting. International Journal of Current Microbiology and Applied Sciences, 3(8), 1021-1028.

Mashur, Djajakirana, G., Muladno, \& Sihombing, D. T. H. (2001). Kajian perbaikan teknologi budidaya cacing tanah Eisenia fetida Savigny untuk meningkatkan produksi biomassa dan kualitas eksmecat dengan memanfaatkan limbah organik sebagai media. Media Peternakan, 24(1), 28-48.

Molina, M. J., Soriano, M. D., Ingelmo, F., \& Llinares, J. (2013). Stabilisation of sewage sludge and vinasse bio-wastes by vermicomposting with rabbit manure using Eisenia fetida. Bioresource Technology, 137, 88-97.

Monebi, C. O., \& Ungwumba, A. A. A. (2013). Utilization of earthworm, Eudrilus euginae in the diet of Heteroclarias fingerlings. International Journal of Fisheries and Aquaculture, 5(2),19-25.

Monroy, F., Aira, M., Domínguez, J., \& Velando, A. (2006). Seasonal population dynamics of Eisenia fetida (Savigny, 1826) (Oligochaeta, Lumbricidae) 
in the field. Comptes Rendus Biologies, 329(11), 912-915.

Ngo, P. T., Rumpel, C., Dignac, M. F., Billou, D., Duc, T. T., \& Jouquet, P. (2011). Transformation of buffalo manure by composting or vermicomposting to rehabilitate degraded tropical soils. Ecological Engineering, 37(2), 269-276.

Ozgunay, H., Colak, S., Mutlu, M. M., \& Akyuz, F. (2007). Characterization of leather industry wastes. Polish Journal of Environmental Studies, 16(6), 867-873.

Paul, J. J., Karmegam, N., \& Daniel, T. (2011). Municipal solid waste (MSW) vermicomposting with an epigeic earthworm, Perionyx ceylanensis Mich. Bioresource Technology, 102(12), 67696773.

Prakash, M., \& Karmegam, N. (2010). Dynamics of nutrients and microflora during vermicomposting of mango leaf litter (Mangifera indica) using Perionyx ceylanensis. International Journal of Global Environmental Issues, 10(3), 339-353.

Pramanik, P., \& Chung, Y. R. (2011). Changes in fungal population of fly ash and vinasse mixture during vermicomposting by Eudrilus eugeniae and Eisenia fetida: Documentation of cellulase isozymes in vermicompost. Waste Management, 31(6), 1169-1175.

Prayitno, P. (2013). Pembuatan vermikompos menggunakan limbah fleshing di industri penyamakan kulit. Majalah Kulit, Karet, dan Plastik, 29(2), 74-84.
Prayitno, P. (2015). Vermikomposting limbah fleshing industri kulit untuk tanaman cabai merah (Capsicum annuum L.). Jurnal Riset Industri, 9(1), 33-38.

Raphael, K., \& Velmourougane, K. (2011). Chemical and microbiological changes during vermicomposting of coffee pulp using exotic (Eudrilus eugeniae) and native earthworm (Perionyx ceylanesis) species. Biodegradation, 22(3), 497-507.

Roslim, D. I., Nastiti, D.S., \& Herman (2013). Karakter morphologi dan pertumbuhan tiga jenis cacing tanah lokal Pekanbaru pada dua macam media pertumbuhan. Biosaintifika: Journal of Biology and Biology Education, 5(1), 1-9.

Pattnaik, S., \& Reddy, M. V. (2012). Remediation of heavy metals fromurban waste by vermicomposting using earthworms: Eudrilus eugeniae, Eisenia fetida and Perionyx excavatus. International Journal of Environment and Waste Management, 10(2), 284-296.

Siddique, J., Khan, A. A., Hussain, I., \& Akher, S.(2005). Growth and reproduction of earthworm (Eisenia fetida) in different organic media. Pakistan Journal of Zoology, 37(3), 211-214.

Singh, D., \& Suthar, S. (2012). Vermicomposting of herbal pharmaceutical industry waste: Earthworm growth, plant-available nutrient and microbial quality of end materials. Bioresource Technology, $112,179-185$. 